\title{
Literary Translation, Between Loss and Compensation
}

\author{
Dr. Anila Mullahi \\ Department of the Albanian Literature in the Faculty of Philology, \\ Tirana University, Albania. \\ anilamullahi@gmail.com
}

\section{Doi:10.5901/jesr.2013.v3n7p312}

\begin{abstract}
Natural languages are perfect exactly because they are numerous, because truth is multi-faceted, whereas the lie consists in representation of truth as unique, final and indisputable. Each language represents a mirror of a tradition and history of development of the people speaking this language, and a future distinguishing it from other languages. But, language is a possibility of separation from the ones speaking different languages. The geo-political changes in the Europe of the XXth century promoted the will for the recognition and assessment of minority languages and allowed for many languages within states as a right to free expression and individual freedom. It is exactly in this moment that the urge for cultural exchange was felt, which differs a lot from assimilation and homogeneity. Therefore, the need for intermediation - that is the need for translation -- has risen a long time ago
\end{abstract}

\section{Historical Development of Translation and Its Role}

Hermeneutics is taken as a starting point of translation, which oldest meaning is the art of interpretation (decoding) of texts. Efforts of bringing of the Homerian texts and texts from other famous personalities of antiquity in a more processed form approaching to New Greek (texts which had evolved a lot from the old Greek), can be referred to as first models of the hermeneutic work. Paraphrases, which can be regarded as a proceeding phase to translation, were used in order to provide more comprehensive texts. Paraphrasing offered summarized texts, providing a mixture of comments and translations, which required a preliminary understanding of the text that could guarantee a more accurate translation of the text. ${ }^{1}$

The need for translation grew parallel to dissemination of Christianity, which got also dispersed in the Greek world. Hermeneutica Sacra, which dealt with the translation of the Bible and other sacred texts, imposed several difficulties, involving not a word-for-word approach, but a textual approach. A great role in defining the methodological definition of the hermeneutic approach on the religious texts was offered by Saint Aurel Agustin.

- In the Roman period translation was widely-spread and was regarded as a way for enriching the mother tongue through creation of new words via natural word exchanges. In the first century B.C. Quintilian did constantly advice for the translation of texts from Greek into Latin, taking into consideration development of the vivid artistic imagination of students.

- In the IXth century, King Alfred considered translation as a useful instrument to disseminate knowledge coming to the help of culturing a nation.

- In the XIllth century, Roger Bacon 1214-1292 speaks of the loss problems during translation, and about the contrary - that is word formation.

- Sacred texts and the Bible were not allowed to be translated in the medieval times. Etienne Dolet (1503-1546)

\footnotetext{
${ }^{1}$ In 1959, Roman Jakobson; "On the linguistic aspect of translation" classified this process as intralinguistic translation; (rewording), in one of three types of translation. He suggested that there are three types of translation; ( a. Intralinguistic translation; (rewording), interpretation of verbal signs by means of other signs of the same language, b. Interlinguistic translation occurs when a text is translated from one language to another, in other words, when we have an interpretation of verbal sights by means of a signs of some other language" (which is translation proper).c. Intersemiotic translation occurs when we have "an interpretation of verbal sight by means of signs of non-verbal sign systems' for example a novel is 'translated' into a film, a poem in a ballet. Jacobson proposed the term "transmutation".
} 
was tortured and hanged as a heretic due to the pretentious deliberate mistakes in translating Platon's dialogues, a mistake related to the distrust in the undeath of the spirit, which in fact derived from Platon being a pagan.

- At the renaissance period, translation is no longer a second-hand activity, but a primary issue and was transformed into a state and religion issue.

- In the XVII- XVIIIth century, writers turned their eyes to antiquity, augmenting the translation volume. R. Descartes, Alexander Pope, J. W. Goethe value translation and the way who it was realized.

- In the Romanticism area, when creativity did almost become a mystic art, there was a sparking individuality amongst opinions regarding translation as a thinking process, but there were also people thinking that translation was a mechanical work. For instance, Shell considered translation as an activity of a lower importance than the activity of a poet.

- Even in the second half of the XIXth century, translators were again seen as a means to communicate to the reader when the original talks could not be understood. Thus, translation was no longer considered as a means for enriching the mother language. It is enough to recall Henri Longfellow (1807-1881), who was of the opinion that the translator was not a poet, nor a commentator, but a mere technical worker.

- It was only in the first half of the XXth century that translation started to be regarded as an inter-disciplinary science.

In the current conditions, when boundaries have become totally and entirely administrative, communication has not become a pragmatic need, but a spiritual need. The number of people speaking more than a language has risen, but, no one can be proficient in all languages. As frequently as we run across something not belonging to the national literature, we come across the translation role, but we hardly mention it. It is infrequent that we appraise the translation of a book when the translated book seems nice to us. "During the reading process of works of foreign authors, the translator is a third person staying in the shadow and shedding light. A light, which is similar to the candles' light. In fact, it is the flakes of this discreet light enlightening communication between the author and the reader. It is light that is the quality of these flakes, the one that realizes a good and much-longed-for communication" (Marashi, 1996).

Albanian is spoken by a relatively small population; therefore, the number of people intercommunicating making use of this language is limited. The first translation known in Albanian is the "Messhar" of Gjon Buzuku, dating back in 1555. Messes documented in Albanian were product of the work of church servants, who, by translation in the mother tongue of some sacred pieces of writings tried to serve distribution of the religion and use of the national language.

In 1944-1990, the possibility of getting to know authors of world literature was very limited. The overwhelming part of the writers of the world literature, in particular, the writers of the XXth century, and more specifically authors of Western counties and of the U.S. literature did not allow for translation of their work, nor were they allowed to be disseminated in their original languages in the territory of Albania. Only some writers were translated at this period, who, in most of cases were Russians or writers that belonged to the previous centuries -- that is translation was allowed only for non-contemporary writers.

There were not a few cases when a translated book back then did not have the name of the translator because of the unimportance attached to the translator's job, and mainly because of the political dislikes attached to certain translators.

After the '90s, collapse of communism in Albania offered more space for inter-human communication and, thereof, inter-literary communication. At the beginning of the ' $90 \mathrm{~s}$, there was a huge wave of individuals trying to do translations and offering translations of various levels. Lack of tradition and ignorance about the profession of translation led to circulation of badly translated or highly disputable (translated) books in Albania in the period from 1990-2000. Plagiarism was also highly present. The ones dealing with translation were quite often people having a very good command of the foreign language, but not a good command of the grammatical structures and lexical wealth of the mother tongue. Sometimes, they had a very good command of the source language and of the target language, but knew nothing of the translation technique and specificities of the art of translation.

Most frequent translations are the ones resulting from the languages belonging to the same family or branch of families, because of the similarities existing between such languages. Albanian belongs to the Indo-European languages, but is a special branch of such languages, characterized of great and unrepeatable peculiarities. Peculiarity of the Albanian language is an urge for the necessity of translation of written texts into Albanian.

Every translator from Albanian or into Albanian is required to have a very good mastery of the features and specificities of each language vis-à-vis other languages. Language is a living instrument, which changes, improves in parallel to the spiritual and the technical development of the people/s speaking it and represents unrepeatable 
peculiarities. If people do not talk the same language, they do not understand one-another, and if they fail to understand one-another they would be missing a huge opportunity (that is socializing). People are social human beings, and the wider the communication is, the more social people would become. Translation facilitates communication and undertakes the responsibility to overcome the separating role of linguistic diversity.

\begin{abstract}
"Translation performs such a task by expressing the same thing in a different language. This is the basic anatomy of the translation process, related to accurate understanding of the notions of equivalence and identity. This anatomy obligates the translator to have a profound mastery of his/her own language, with the purpose of finding accurate equivalents for expressing exactly the same thing denoted in the other language" (Marashi 1996).
\end{abstract}

Translation undertakes to ensure intermediation between the departing language, that is the language of the original, and the destination language, that is the language of the translated document. Given that the translator deals with the final text of another person (author), he has to be loyal to the original text. But, we should also highlight that a translator's job is not mechanical, but he is, instead, an interpreter of the author of the original text. In conditions when one word has more than one meaning, in the conditions when a word can be replaced by many other words, by way of establishing synonymic networks, the translator plays the role of an artist in choosing the exact words, forms and styles that would best serve the ultimate purpose - that is representation of the original text.

The translator finds an in-between position between loyalty and understanding and freedom of choosing the right wording. Umberto Eco in Experience in translation draws on his substantial practical experience and he convincingly demonstrates that translation can express an evident deep sense of a text even when violating both lexical and referential faithfulness (Eco, 2001).

Trying to do the best possible with the text, the translator tries not to touch the artistic level of the original text, and manages to do so by, first, trying to have as little loss possible in the course of translation, and by, second, compensating the loss with his creative capacities. In the history of translation this is normal, but the translators should be conscious about not considering themselves "co-authors". There are translations that splendidly enrich the target language and that, in few cases, considered as miracles by many, manage to say more (in other worlds, provide richer texts in the target language) than in the original texts. But, in fact, these translations are usually valuable in themselves as original works of art, and not as version of a source text. A translation that manages "to say more" might be an excellent piece of work in itself, but it is not a good translation (Eco, 2001). The translator does not have to use his liberty, unless for reasons related to better putting to the fore of the idea/message of the author.

Often times, when discussions are held on the specificity of translations of the literary texts, they say that it is needed for the translator to establish an intimate relation with the text subject to translation and penetrate in the world of feelings of the poet. One should have the spirit of a poet to be able to translate an artistic work

The artistic translation is a cell shaped not in the biologist's or a chemist's lab, but in the poet's spirit lab, in the eyes' tear, in the spirit breath and in the blood, first emerging from heart, and then transformed in the energy of the pen, -this is how Kokona, one of the greatest translators of Albania writes (Kokona, 2003).

It is often said that translation of an artistic works is facilitated a lot by translation by a person who is himself a writer. In the world literature and in the Albanian literature, there are many cases when writers are translators as well, such as Goethe, Mallarmè, Baudelaire, L. Poradeci, Fan Noli, Ismail Kadare, Mitrush Kuteli, etc. Whereas in the case of translation from writers, a remarkable feature is that usually translators prefer to translate works from which they identify something from themselves. For instance, the greatest Albanian lyric poet Hajnen, the greatest Albanian writer known for bringing the behavior of tragedy and universality of feelings in his work, has translated Eskilis. Similarity, a similar writing style of the translator with what he/she translates is not an indispensable condition, because a real translator can translate even something not falling part of his/her style, as long as he/she enters in the depth of the spirit and of the sensuality of the author.

The relationship between the writer and the translator has always caused controversies. The history of literary developments has shown great translators have proven to be not great writers and the vice-versa. W. Benjamin says: "Given that translation is a special form of creation, the task of the translator can also be regarded as special and clearly separated from the task of the poet. The task of the translator is to find the appropriate intention in the target language, so that this intention gives the spirit of the original" (Benjamin 1998, [1923]:56). When he writes, the writer is totally and entirely spontaneous, free, unreachable, whereas the translator is limited from the text in the original.

The archetype literary terms are found at any time and any century from various writers, but it is the entirely 
different treatment rendering them fully distinguishable. The fable of the work is one part of it, whereas another important part, and even the most complicated one, is the form and style of writing. The writer style is very individual and easily distinguishable from that of another writer. The task of the translator is to offer such a peculiarity to the readers of the target language.

While translating literary texts, the translators should not only understand the linguistic denotation, but even the specific way of its use by the author. Authors play with words, with their various forms or with the use of words, and all these maneuvers are not casual, but deliberate, and this is why it is very important for the translator to transmit such peculiarities in the translated text. The literary texts, in particular the modern ones, have a multitude of interpretations and a hidden emotionality, which can be identified and understood only by a couscous reader. The translator has to be a very couscous reader, who, by means of his/her text, manages to transmit all the meanings contained in a text in the entirety and in-between the lines.

No matter how loyal a translator is, while translating, the translator carries the text through his subjective feelings and choices. Thus, the translation does not always have a guaranteed quality, and this is why frequently the same text needs to be translated from different translators. There is no such thing as perfect translation. "Today, the translator resembles a modern syphilis"( Kokona 2003).

Translation of a poetic text is more difficult than translation of any other text. This is why poetic translations often aim at having a radical review as a challenge to the text in original, but according to the principle of inspiration, which definition depends, as seen, on the critical interpretation of the translator (Eco 2001). One should be very careful when translating poetries. Rhetoric recognizes figures of content (like metaphor, synonym, or oxymoron) in which the substance of the expression is not pertinent, but also in figures of expression like assonance, paronomasia, alliteration. The expressive substance likewise becomes fundamental with regard to phonosymbolic issues and to discursive rhythm in general. Rhyme is like wise perceptible as the substance of the expression, even if it exploits elements already supplied by the lexical system (Benjamin 1998 [1923]: 88).

The British and French, at the end of the XXth century, have shown skepticism on translation of works written in lines in their languages, and have further been in favour of a solution including poetry prose.

\section{Translation and success}

Stemming from the decisive role of translation for making a book known in many countries of the world, there are scholars and translators recognizing a great role to it in the route of achieving fame and success. But, there are also scholars saying that translation, no matter how good it is, cannot play a considerable role in ensuring a success to the book, if the book in itself is not successful in the original language. "It is clear that translation, no matter how good it is, has no importance whatsoever to the original" says Benjamin. Translation comes after the process of writing of the original work, and often it is said that the work finds its translator not in the era/time it is written. The work in original gets its fame because of its existence, which is separate from the existence or non-existence of a writer. The continuity of reading of books in times different from the writing time means that the work is successful. In general, translation happens when the text in the original has been successful and it is in another phase of the work existence that translation comes into play ensuring a longer useful and successful life of the book. The translator relates his/her work with the success of the work in the original, whereas the contrary is not true - that is translation can never make a book successful. Translation plays an intermediary role to fame and success of the book author. Translation is a rigorously scientific work, in which process prevalence of the text in the original is de facto perceived vis-à-vis relations to translation" (Benjamin 1996 [1923]: 52). Despite any kind of discourse, translation is a process offering a practical choice to the readers to feel and experience, via translation, the same emotions felt and experienced by the one reading the book in the original language.

\section{References}

Marashi, Ardian, "Përkthimi para gjyqit", Studim krahasues, (Translation before Court of Law, A Comparative Study) At Gjergj Fishta, Shkodër 1996.

Benjamin Walter, "Iluminations", Korbi, Tirana, 1998

Eco, Umberto, "Experiences in Translation", University of Toronto Press, Toronto Buffalo London, 2001.

Eco Umberto, "Të thuash gati të njëjtën gjë. Përvoja përkthimi", (Saying almost the same Thing, Translation Experiences) Tirana, Dituria 2006, p. 314 
Kokona, Vedat, "Mbi përkthimin, me përkthyesin" (On translation, with the translator), Tirana, Kokona 2003

Jakobson, Roman (1959/2004) "On linguistic aspects of translation", The Translation Studies Reader, 2nd edition, pp. 138-43. 